\title{
A Genre Analysis of the Texts in English Textbook "Pathway to English" Used by Tenth Grade Students
}

\author{
Andrian Nuriza Johan ${ }^{a}$, Gunawan Panji Krismono ${ }^{b}$, Juita Triana ${ }^{c}$ \\ ${ }^{a, b, c}$ Muhammadiyah University of Purworejo, Purworejo \\ Email of corresponding author: andrianjohan41@gmail.com
}

\begin{abstract}
This study aims to find out the text genres, the generic structure and language features in English textbook Pathway to English used by tenth grade students. This study analyzed the genre of the text, generic structure, and language features. A descriptive qualitative method is used to analyze the genre in Pathway to English textbook. There were four genres found in collecting data, descriptive text, narrative text, recount text, and announcement text. Then the researcher analyzing the generic structure and language features used in the text. After analyzing the data, the researcher found that from 18 texts taken, 4 texts $(22 \%)$ data were descriptive text, 5 texts $(28 \%)$ data were narrative text, 5 texts $(28 \%)$ data were recount text, and 4 texts $(22 \%)$ data belonged to announcement text. Based on the theories, the generic structure and the language features of each genre found in Pathway to English textbook were correct in English.
\end{abstract}

Keywords: genre, text, textbook

\section{INTRODUCTION}

English is an international language that is regularly used to communicate between countries. In Indonesia, English is considered a foreign language. English has been taught at elementary, middle, and high schools, including at colleges, for the essentials. Learning English involves the use of media that support in the learning process, one of which is books or textbooks. Textbooks are important media in the learning process both in general, and specifically for example in language learning (Ayu, 2020). This is also emphasized by (Cunningsworth, 1995) which states that English Textbook have a variety of roles which include a tool for introducing written and spoken, encouraging interaction, providing references for grammar and vocabulary, acting as a source for classroom activities and offers work that can assessed by students independently and provides self-directed learning. Furthermore, One of the factors determining the success of students in use textbooks that are determined by the quality of these textbooks (Anizar et al., 2019) . In addition, Text book unquestionably plays a major contribution in supporting the existing curriculum being implemented (Dharma \& Aristo, 2018). According to (Tomlinson, 2011) textbook or coursebook is the common teaching material is a book which provides the core materials for language learning. Furthermore, Teaching materials can take important role in language learning (Sari et al., 2018). Teaching materials can inform learners about the language, provide experience of the language in use, and help learners to make discoveries about the language for themselves (Nikoopour \& Farsani, 2011). As a result, the 
significance of the textbook in English has attracted educators and researchers to analyze it from several aspects (Ayu \& Indrawati, 2018).

English as foreign language in Indonesia makes reading skill critical since Indonesian English users tend to more oriented toward getting engaged in written communication than oral communication (Lauder, 2008). The variety of English Reading skill has been evident in the educational curriculum of Indonesia since the application of competency based curriculum or KBK, 2006's curriculum or the so-called KTSP, and today's K13 curriculum (Setyono \& Widodo, 2019). Genre itself is one of the basic elements in teaching reading. In language learning, genre is one of the most essential and influential topics(Hyland, 2004). Genre is needed by the students in conversation as it offers linguistic implications the students have to notice. Genre-based instruction is an approach to teaching a language underpinned by a constructivist paradigm (Vygotsky, 1978). This approach views the staging of communication from the presence of various genres. In this regard, genres are the realistic representations of language uses wherein genres portray the purposes, contexts, and discourses of communication (Fauziati, 2014). In terms of reading, genres determine the extent to which a reader can comprehend a text read (Dickens \& Meisinger, 2017). Genres are also the representations of language uses based on the existing sociocultural and multicultural contexts. Since Indonesian people (or students in the realm of education) are culturally different and linguistically diverse in terms of their vernaculars, the use of English as a foreign language always comes across multilingual and multicultural settings (Kirkpatrick, 2018)(Mauranen, 2018)(Morganna et al., 2020). Thus, the role of genres is more critical in Indonesian students' English usage. Since the enactment of the KBK curriculum, which was followed by the KTSP curriculum, the term "genre-based instruction" has been widely used in Indonesia, but the term now refers to a scientific approach in the K-13 curriculum. By understanding the genre, students can not only use English sentences but also organize text content in the same way that native speakers do. Despite being a fundamental component of learning to read, the genre of the text is frequently confused with other genres by students. Students continue to be perplexed by text genres such as narrative text and descriptive text, as well as book genres such as romance, comedy, and crime. Additionally, students are perplexed as to which language features are used in each genre of text. While structure text is the most easily understood by the student. Certainly, this is a barrier, as the 2013 curriculum is used in almost every school today. Students were expected to be more active and self-directed learners in the 2013 curriculum by reading more books, while the teacher was expected to serve as a conduit for students to ask questions about the topic.

At last, considering to the facts above, it necessary to investigate the content of the text book. Therefore, this study tries to find out text genres, the generic structure, and the language features of the text found in "Pathway to English" textbook.

\section{METHOD}

The researchers used a qualitative descriptive method. Qualitative research is a technique for analyzing and interpreting the meaning given to a social or human issue by individuals 
or groups. Through qualitative research, the researcher can identify the subject and feel what she does in her daily activities. The purpose of this research was to conduct a genre analysis of a Senior High School textbook used in tenth grade. This method was chosen because analyzing data from a book and then explaining it in a nutshell, as the subject of this research, is a form of creative work that is universally interpretable.

The subject from which the information can be obtained is referred to as the data source. The reading texts found in the Pathway to English textbook for Tenth Grade Senior High School students in SMA 2 Purworejo serve as the data source for this study. Identifying, classifying, calculating the percentage, discussing, describing, and drawing a conclusion were the steps in data analysis.

\section{FINDINGS AND DISCUSSION}

This section identifies the data through the genre of texts in English textbook Pathway to English. Below is a data related to genres from 14 texts in English textbook Pathway to English. The data is illustrated in Table 1 below

Table 1 The Genres Found in the Textbook

\begin{tabular}{cccc}
\hline No. & Genre Text & Amount & Percentage \\
\hline 1. & Descriptive Text & 4 & $22 \%$ \\
\hline 2. & Recount Text & 5 & $28 \%$ \\
\hline 3. & Narrative Text & 5 & $28 \%$ \\
\hline 4. & Announcement & 4 & $22 \%$ \\
\hline
\end{tabular}

Descriptive Text

Text 1

The researcher finds the text is descriptive and the social function is to describe about Semarang City.

Generic Structure :

\begin{tabular}{|l|l|}
\hline \multirow{7}{*}{ Identification } & $\begin{array}{l}\text { Semarang city, the capital of Central Java } \\
\text { Province, is located on the northern coast of } \\
\text { Java island. Like all municipalities in } \\
\text { Indonesia, it is led by a mayor. The southern } \\
\text { parts of the city are higher than its northern } \\
\text { parts. The city covers an area of over } 200 \\
\text { square km. It is divided into 16 kecamatan or } \\
\text { sub-districts. Similar to all regions in } \\
\text { Indonesia, Semarang has a tropical climate, } \\
\text { with wet and dry seasons. }\end{array}$ \\
\hline
\end{tabular}




\begin{tabular}{|c|c|}
\hline Description & $\begin{array}{l}\text { As of 2015, the population of Semarang City } \\
\text { has reached } 1.8 \text { million, placing it fifth in the } \\
\text { list of most dense cities in Indonesia. The } \\
\text { people are predominantly Javanes, but it } \\
\text { also has a considerably high number of } \\
\text { people of Chinese ethnicity. Bahasa } \\
\text { Indonesia and Javanese are the main } \\
\text { languages spoken in the city. The population } \\
\text { of Chinese ethnicity also speaks Mandarin or } \\
\text { Hokkien. } \\
\text { As there are many people of Chinese } \\
\text { ethnicity in Semarang, many Chinese } \\
\text { temples were built as their places of worship. } \\
\text { The Sam Poo Kong is the oldest in } \\
\text { Semarang. Other historical landmarks in the } \\
\text { city include Tugu Muda, Bleduk Church, and } \\
\text { Lawang Sewu. Tugu Muda is a monument } \\
\text { commemorating Indonesia's independence } \\
\text { struggle. Bleduk Chruch is a Protestant } \\
\text { chruch built by the Dutch in 1753. Lawang } \\
\text { Sewu was built as the headquarters of Dutch } \\
\text { East Indies Railway Company. It is famous } \\
\text { for its numerous doors, hence the name, } \\
\text { literally meaning "thousand doors". }\end{array}$ \\
\hline
\end{tabular}

The researcher has analyzed the structure of the text 1, and then the researcher analyzed the language features on the text 1 :

\begin{tabular}{|l|c|}
\hline \multicolumn{1}{|c|}{ Language Feature } & \multicolumn{1}{c|}{ Words } \\
\hline Focus on specific participants & $\begin{array}{l}\text { Semarang city, the capital of } \\
\text { Central Java Province }\end{array}$ \\
\hline $\begin{array}{l}\text { Use of attribute and } \\
\text { identifying process }\end{array}$ & $\begin{array}{r}\text { a. The city covers an area of } \\
\text { over 200 square km. } \\
\text { b. It is divided into 16 } \\
\text { kecamatan or sub-districts. } \\
\text { c. Similar to all regions in } \\
\text { Indonesia, Semarang has a } \\
\text { tropical climate, with wet } \\
\text { and dry seasons. }\end{array}$ \\
\hline $\begin{array}{l}\text { Frequent use of epithets and } \\
\text { Classifier in nominal group }\end{array}$ & $\begin{array}{l}\text { Other historical } \\
\text { landmarks in the city } \\
\text { include Tugu Muda, } \\
\text { Bleduk Church, and }\end{array}$ \\
\hline
\end{tabular}




\begin{tabular}{|c|c|}
\hline & $\begin{array}{l}\text { Lawang Sewu. } \\
\text { b. The city covers an area } \\
\text { of over } 200 \text { square } \mathrm{km} .\end{array}$ \\
\hline Use of simple present & $\begin{array}{l}\text { a. Bleduk Chruch is a } \\
\text { Protestant chruch built } \\
\text { by the Dutch in } 1753 . \\
\text { b. The Sam Poo Kong is the } \\
\text { oldest in Semarang. }\end{array}$ \\
\hline
\end{tabular}

\section{Recount Text}

\section{Text 5}

The researcher found that social function text 5 is to retell events about The Invention of the Telephone.

Generic Structure:

\begin{tabular}{|c|c|}
\hline Orientation & $\begin{array}{l}\text { Alexander Graham Bell was a Scottish- } \\
\text { born American teacher and scientist. } \\
\text { While experimenting on the telegreph in } \\
\text { 1870, he found it possible to transmit the } \\
\text { human voice over a wire by using } \\
\text { electricity. }\end{array}$ \\
\hline Sequence of events & $\begin{array}{l}\text { To make up for his lack of time and skill to } \\
\text { make the equipment for his experiments, } \\
\text { he invited Thomas A. Watson to join him. } \\
\text { The two became best friends and } \\
\text { colleagues. } \\
\text { On June 2, 1875, while Bell was at one } \\
\text { end of the line and Watson worked on the } \\
\text { reeds of the telegraph in another room, } \\
\text { Bell heard a sound over the wire. The next } \\
\text { day, the instrument transmitted sound, not } \\
\text { words. }\end{array}$ \\
\hline Re-orientation & $\begin{array}{l}\text { In September 1875, Bell and Watson kept } \\
\text { working to improve the instrument. By } \\
\text { March 1876, Bell managed to make a } \\
\text { transmission, but the sound was faint. He } \\
\text { called his instrument a "telephone". Bell } \\
\text { improved on the instrument, and on March } \\
\text { 10, it carried its first meaningful }\end{array}$ \\
\hline
\end{tabular}


senternce. Bell's telephone was so famous

that he patented it. The first telephones

were installed the following year.

The researcher has analyzed the structure of the text 5 , and then the researcher analyzed the language features on the text 5 :

\begin{tabular}{|c|c|}
\hline Language Feature & Words \\
\hline $\begin{array}{l}\text { Focus on specific } \\
\text { participant }\end{array}$ & $\begin{array}{l}\text { Alexander Graham Bell was a } \\
\text { Scottish-born American } \\
\text { teacher and scientist. }\end{array}$ \\
\hline Use of material process & $\begin{array}{l}\text { The two became best friends } \\
\text { and colleagues. } \\
\text { While experimenting on the } \\
\text { telegreph in } 1870 \text {, he found it } \\
\text { possible to transmit the } \\
\text { human voice over a wire by } \\
\text { using electricity. }\end{array}$ \\
\hline $\begin{array}{l}\text { Use circumstance of } \\
\text { time and place. }\end{array}$ & $\begin{array}{l}\text { On June 2, 1875, while Bell } \\
\text { was at one end of the line and } \\
\text { Watson worked on the reeds } \\
\text { of the telegraph in another } \\
\text { room } \\
\text { In September 1875, Bell and } \\
\text { Watson kept working to } \\
\text { improve the instrument. } \\
\text { By March 1876, Bell managed } \\
\text { to make a transmission, but } \\
\text { the sound was faint. }\end{array}$ \\
\hline Use simple past tense & $\begin{array}{l}\text { Bell was at one end of the line } \\
\text { and Watson worked on the } \\
\text { reeds of the telegraph in } \\
\text { another room. } \\
\text { By March 1876, Bell managed } \\
\text { to make a transmission, but } \\
\text { the sound was faint. }\end{array}$ \\
\hline Use of adjective & $\begin{array}{l}\text { Faint } \\
\text { Best } \\
\text { Lack }\end{array}$ \\
\hline
\end{tabular}




\section{Text 9}

The researcher found that social function text 3 is to entertaint the reader with folktale or legend from Maluku, "Batu Badaun".

Generic Structure:

\begin{tabular}{|l|l|}
\hline Orientation & $\begin{array}{l}\text { A long time ago, on Tanimbar Island, } \\
\text { Maluku, there lived a widow and her two } \\
\text { children, a boy and a girl. The children } \\
\text { were mean and spoiled. They never knew } \\
\text { hard work and neither did they help their } \\
\text { mother with the household chores. }\end{array}$ \\
\hline Complication & \begin{tabular}{l} 
One day, they woke up when the sun was \\
already high. They went to the kitchen to \\
look for food, but nothing was served. The \\
food was still being cooked but their \\
mother was not around. They smashed the \\
cooking pots in rage. \\
They went to look for their mother and \\
found her washing their clothes at the \\
river. They complained to and shouted at \\
her. It made the widow cry. \\
Suddenly, she stopped crying. She said to \\
her children, "From now on you are no \\
longer my children. Do whatever you \\
want. I'm not coming back home." \\
\hline Re-orientation \\
Then the widow went to a big rockby a said, "Please open up, big rock. \\
Let me come inside you and become a \\
white, sweet-smelling flower." The big \\
rock opened up. She went inside and the \\
rock closed over her. \\
After a few day, a small plant started \\
growing under the big rock. White, sweet- \\
smelling flowers bloomed from it. It had a \\
lot of leaves as well. The villagers called \\
the big rock Batu Badaun. \\
What happened to the widow's childern? \\
The cruel children were forced to leave by \\
the angry villagers. They were never heard \\
of again.
\end{tabular} \\
\hline Resolion \\
\hline
\end{tabular}


The researcher has analyzed the structure of the text 9, and then the researcher analyzed the language features on the text 9 :

\begin{tabular}{|c|c|}
\hline Language Feature & Words \\
\hline $\begin{array}{l}\text { Specific, often individual } \\
\text { participants with defined } \\
\text { identities. }\end{array}$ & $\begin{array}{l}\text { A long time ago, on Tanimbar } \\
\text { Island, Maluku, there lived a } \\
\text { widow and her two children, a } \\
\text { boy and a girl. }\end{array}$ \\
\hline Mainly action verb & $\begin{array}{l}\text { Washing } \\
\text { Crying } \\
\text { Went } \\
\text { Growing } \\
\text { Look }\end{array}$ \\
\hline Usually using past tense & $\begin{array}{l}\text { They complained to and } \\
\text { shouted at her. } \\
\text { After a few day, a small plant } \\
\text { started growing under the big } \\
\text { rock. } \\
\text { The villagers called the big rock } \\
\text { Batu Badaun. }\end{array}$ \\
\hline $\begin{array}{l}\text { Time connectives and } \\
\text { conjunctions }\end{array}$ & $\begin{array}{l}\text { After a few day } \\
\text { Then } \\
\text { One day } \\
\text { A long time ago }\end{array}$ \\
\hline $\begin{array}{l}\text { Can be written in the } \\
\text { first-person perspective } \\
\text { or third person }\end{array}$ & $\begin{array}{l}\text { Written in third person } \\
\text { perspective. }\end{array}$ \\
\hline
\end{tabular}

Announcement

Text 13

The researcher found out social function text 13 is anouncement of information about basketball competition 
Generic Structure :

\begin{tabular}{|l|l|}
\hline Stating purpose & $\begin{array}{l}\text { To celebrate the anniversary of SMA } \\
\text { negeri 5, Semarang, the Student's School } \\
\text { Organization will hold a goodwill } \\
\text { basketball competition. }\end{array}$ \\
\hline $\begin{array}{l}\text { Stating day, date, time, } \\
\text { and place }\end{array}$ & $\begin{array}{l}\text { The competition will be held: } \\
\text { Date }: 25-30 \text { June } \\
\text { Time }: 9 \text { a.m. and } 3 \text { p.m. } \\
\text { Venue : SMA } 5 \text { basket ball courtyard } \\
\text { The school teams who will participate in } \\
\text { this competition should pay the enrollment } \\
\text { fee, Rp. } 100.000, .\end{array}$ \\
\hline $\begin{array}{l}\text { For further information, contact: } \\
\text { Heru@g-mail.com or call } 35447893\end{array}$ \\
\hline
\end{tabular}

The researcher has analyzed the structure of the text 13, and then the researcher analyzed the language features on the text 13 :

\begin{tabular}{|c|c|}
\hline Language Feature & Words \\
\hline $\begin{array}{l}\text { Using simple present } \\
\text { tense and simple future } \\
\text { tense }\end{array}$ & $\begin{array}{l}\text { To celebrate the anniversary of SMA } \\
\text { negeri 5, Semarang, the Student's } \\
\text { School Organization will hold a } \\
\text { goodwill basketball competition } \\
\text { The school teams who will participate } \\
\text { in this competition should pay the } \\
\text { enrollmentfee, Rp. } 100.000 \text {,. }\end{array}$ \\
\hline Using exact noun & $\begin{array}{l}\text { Basketball } \\
\text { enrollmentfee }\end{array}$ \\
\hline $\begin{array}{ll}\text { Spelling } & \text { and } \\
\text { Punctuation } & \end{array}$ & $\begin{array}{l}\text { celebrate } \\
\text { Organization }\end{array}$ \\
\hline
\end{tabular}

The data were classified into 4 genres of text. From 18 texts which are taken by the researcher, 4 texts $(22 \%)$ data belong to descriptive text, 5 texts $(28 \%)$ data belong to recount text, 5 texts $(28 \%)$ data belong to narrative text, and 4 texts $(22 \%)$ data belong to announcement text. 


\section{Descriptive}

Description texts in this chapter are text 1 until text 4 . Text 1 until text 4 has the generic structure of descriptive text which is identification and description. From text 1, language feature in descriptive text focus on the use of specific participant is, "Semarang City", use of attributive and identifying process there are "it, is, the city" frequent use of epithets and classifiers in nominal groups there are "Tugu Muda, Bleduk Church, and Lawang Sewu" and text 1 use of simple present tense. From text 2, language feature in text 2 focuses on the use of specific participant is "Bali" use of attributive and identifying process are "The beautiful island" frequent use of epithets and classifiers in nominal groups are "traditional ceremonies, seasons" and the text use of simple present tense.

From text 3 , the researcher measures it with significant language features in descriptive text focus on the use of specific participant is "Borobudur" use of attributive and identifying process there are "Buddhist temple, The temple" frequent use of epithets and classifiers in nominal groups there are "terraces, Buddhist reliefs" and the use of simple present tense. The last descriptive genre is text 4 , the language feature in descriptive text focuses on the use of specific participant is "Purna Bhakti Pertiwi Museum", use of attributive and identifying process there are "it, displays" frequent use of epithets and classifiers in nominal groups are "main hall, Struggle Hall, special hall", and these use of simple present tense.

\section{Recount}

Based on the generic structure of text 5 until text 8 , the researcher found that the genre is recount text. The generic structures of text 5 until text 8 are orientation, sequence of events, and re-orientation. The researcher also analyzed the language feature of text 5 until text 8. In text 5 language feature in recount text focus on a specific participant is "Alexander Graham Bell", use of material process there are "became, experimenting, following", use of circumstance of time and place there are "On June 2, 1875, In September 1875, by March 1876", use of adjective there are "faint, best, lack", and these use simple past tense.

From text 6, language feature in recount text focus on specific participants are "triple alliance and triple entente", use of material process there are "making, expecting", use of circumstance of time and place there are "On 28 June 1914, on 23 July 1914, in 1914", use of adjective there are "the greatest, brutally", and these use simple past tense.

From text 7, language feature in recount text focus on specific participants are "Niel Armstrong and Buzz Aldrin", use of material process there are "landing, taking", use of circumstance of time and place "at 8.32 p.m. on July 16, Earth, Moon's surface, On Monday 21 July 1969 at 9.55 a.m.", use of adjective there are "greatly, superior, soft", and the use of simple past tense such as "solved, moved, showed".

In text 8 , language feature in recount text focus on a specific participant is "Dr. Alexander Fleming", use of material process there are "entering, discovery, after examination", use of circumstance of time and place there are "in September 1928, in 1945, laboratory", use 
of adjectives there are "useless, dangerous, interesting, success", and these use simple past tense such as "brought, happened, awarded".

\section{Narrative}

The researcher concludes that text 9 until text 12 is categorized as narrative text. It is based on the generic structure which are orientation, complication, resolution, and reorientation. Text 9 until text 12 has a narrative generic structure. In text 9, language feature focus on specific individuals are "a widow and her two children", using action verb such as "washing, crying, went, growing, look", use of time connective and conjunction there are "a long time ago, a few day, one day, then", use of simple past tense such as "knew, woke up, went, smashed", and these using third-person perspective.

From text 10, language feature focus on specific individuals is "unlucky king and his daughter", using action verb such as "marry, send, gave, cooks, work", use of time connective and conjunction there are "one day, when", use of simple past tense such as "gave, started, was", and these using first-person perspective.

From text 11, language feature in narrative text focus on a specific individual is "Serunting", using action verb such as "resumed, spoke, told, meditate", use of time connective and conjunction there are "once upon a time, the next day, from then on", using simple past tense such as "grew, spoke, was, persuaded", and these using third-person perspective.

In text 12 , language feature in narrative text focus on specific individuals are "a miller and his young son", using action verbs such as "driving, walked, followed, carry", use of time connective and conjunction there are "a long time ago, then", using simple past tense such as "met, thought, walked, was", and these using third-person perspective.

\section{Announcement}

The researcher analyzes that text 13 until text 16 is announcement text. It is based on the generic structure of announcement which are stating the purpose, stating day, date, time, and place, informing sender. The researcher found out that text 13 until text 15 has the announcement generic structure, while text 16 missing stating day, date, time, and place.

From text 13, the researcher analyzes language feature in announcement text is using simple future tense such as "held, will", using exact noun such as "basketball, enrollment fee", and using good spelling and punctuation. From text 14, the researcher analyzes language feature in announcement text is using simple future tense such as "will, would like to", using exact noun such as "batik, seminar, workshop", and using good spelling and punctuation.

From text 15, language feature in announcement text is using simple future tense such as "will be", using exact noun which is 'Bachelor of Science Degree", and using good spelling and punctuation. In text 16, the researcher found language feature in announcement text using simple present tense such as "to improve, are", using exact noun 
which is "Basic Windows Computer Final Examination", and using good spelling and punctuation.

Genre was known as a kind of text in English reading, because each genre indicate that has different general structure and language features. Genres can define by looking at the general structure and language features. In the textbook, the generic structure and language feature of the text from each genre are already correct.

\section{CONCLUSION}

The researcher found from the analysis of the "Pathway to English" textbook for the 10th grade high school in the 2020/2021 school year that the textbook contains four genres. They are descriptive, announcement, narrative, narrative.

The researcher found that the generic structure from each genre is different. From descriptive text there are identification and description,. From recount there are orientation, sequence of events, and re-orientation. While narrative there are orientation, conclusion, resolution, and reorientation. Lastly, is announcement with stating purpose, stating day, date, time, place, and information about sender.

The researcher also found that language feature of each genre is different. The researcher found in descriptive text usually using simple present tense, using attribute and identifying process, focus on specific participant, and using epithets and calssifier in nominal group. Recount text also focuses on specific participant, uses material process, using circumstance of time and place, using adjective, and using simple past tense. From narrative text, language feature is also using specific participant, mainly using action verb, usually using past tense, using time connectives and conjuctions, and can be written in the first perspective or third perspective. While announcement text, language feature can use simple present tense or simple future tense, use exact noun, use correct spelling and punctuation.

\section{REFERENCES}

Anizar, N., Saragih, B. N., \& Sinaga, T. W. F. (2019). Teacher's Strategies in Teaching Speaking at SMP Negeri 18 Medan. Journal Edulingua, 6(2), 1-5.

Ayu, M. (2020). Evaluation of Cultural Content on English Textbook Used by EFL Students in Indonesia. Journal of English Teaching, 6(3), 183-192. https://doi.org/https://doi.org/10.33541/jet.v6i3.1925

Ayu, M., \& Indrawati, R. (2018). EFL Textbook Evaluation: The Analysis of Tasks Presented in English Textbook. Teknosastik:, 16(1), 21-25. https://ejurnal.teknokrat.ac.id/index.php/teknosastik/article/view/87

Cunningsworth, A. (1995). Choosing your Coursebook. Oxford. McMillan Publisher Limited.

Dharma, Y. P., \& Aristo, T. J. V. A. (2018). An Analysis of English Textbook Relevance to the 2013 English Curriculum. Journal of English Educational Study, 1(1), 24-33.

Dickens, R. H., \& Meisinger, E. B. (2017). Examining the Effects of Reading Modality 
and Passage Genre on Reading Comprehension in Middle School Students. Rading Psychology, 38(3), 268-282.

Fauziati, E. (2014). Methods of Teaching English as a Foreign Language. Surakarta. Era Pustaka Utama.

Hyland, K. (2004). Genre and Second Language Writing. Michigan. University of Michigan Press.

Kirkpatrick, A. (2018). The Development of English as a Lingua Franca in ASEAN. In J. Jenkins, W. Baker, \& M. Dewey (Eds.), The Routledge Handbook of English as Lingua Faranca (pp. 138-150). New York. Routledge.

Lauder, A. (2008). The Status and Function of English in Indonesia: A Review of Key Factors. Makara, Social Humaniora, 12(1), 9-20.

Mauranen, A. (2018). Conceptualising ELF. In J. Jenkins, W. Baker, \& M. Dewey (Eds.), The Routledge Handbook of English as Lingua Faranca (pp. 7-24).New York .Routledge.

Morganna, R., Sumardi, S., \& Tarjana, S. S. (2020). Tertiary English Students's Attitude towards Intercultural Language Learning. Indonesian Journal of Applied Linguistics, 9(3), 657-665. https://doi.org/https://doi.org/10.17509/ijal.v9i3.23216

Nikoopour, J., \& Farsani, M. A. (2011). English Language Teaching Material Development. Journal of Language and Translation, 2(2), 1-12. http://ttlt.azad.ac.ir/article_531664.html

Sari, I. P., Syafei, A. F. R., \& Fatimah, S. (2018). An Analysis of the Activities in Bahasa Inggris Textbook for 10th Grade Students Published by The Indonesian Ministry of Education and Culture. Journal of English Language Teaching, 7(3), 426-435. http://ejournal.unp.ac.id/index.php/jelt/article/view/100375

Setyono, B., \& Widodo, H. P. (2019). The representation of multicultural values in the Indonesian Ministry of Education and CultureEndorsed EFL textbook: a critical discourse analysis. Intercultural Education, 1-15. https://doi.org/https://doi.org/10.1080/14675986.2019.1548102

Tomlinson, B. (2011). Material Development in Language in Language Teaching (Second). Cambridge. Cambridge University Press.

Vygotsky, L. S. (1978). Mind and Society. Harvard. Harvard University Press. 